\title{
The Impact of Strategic Human Resource Management on Institutionalization Process
}

\author{
Yavuz Yilmaz (Corresponding author) \\ Dept. of Business Administration, Gebze Technical University \\ PO Box 41400, Gebze, Kocaeli, Turkey \\ Tel: 90-262-642-5528. E-mail: yavyil@gmail.com \\ Hakan Kitapci \\ Dept. of Business Administration, Gebze Technical University \\ PO Box 41400, Gebze, Kocaeli, Turkey \\ Tel: 90-262-605-1415. E-mail: hakankitapci@gmail.com
}

Received: June 15, 2017 Accepted: June 24, 2017 Published: December 1, 2017

doi:10.5296/bms.v8i2.11403～URL: https://doi.org/10.5296/bms.v8i2.11403

\begin{abstract}
The purpose of this paper is to examine the mediating role of strategic human resource management between the mechanisms of institutionalization made up institutionalization process and the stages of institutionalization. This issue is researched in the light of data collected through a survey of 125 businesses with human resources department, which are in Kocaeli organized industry region. The assessment of the data is done with structural equation modeling. The analysis shows that strategic human resource management has a positive effect on institutionalization process. The main limitations of this study are the quantity and quality of sample and the number of data that are used in this study. While the researches that examine theoretically the relations between institutional theory and strategic human resource management exist, the hypothesis in this study is analyzed by using empirical data.
\end{abstract}

Keywords: Institutionalization, Strategic human resource management, Structural equation modeling 


\section{Introduction}

Research in the area of human resource management (HRM) focus mainly on the effects of human resources management practices on organizational performance. The research on this topic demonstrates that there is a positive relation between human resources practices and the performance of a company (Boselie et al., 2001; Wan et al., 2002; Boselie et al., 2003; Green et al., 2006; Akhtar et al., 2008; Ngso et al., 2008; Khalid et al., 2011).

Research in strategic human resource management (SHRM) to date has focused mainly on the effects of HRM practices or systems on organizational productivity and effectiveness (Boon et al., 2009). Productivity and effectiveness however, are not the only sources of organizational success. Institutional theory argues that besides effectiveness and financial success, the organization also has to be legitimate in order to survive in the long run (Boon, 2008).

Research on the applicability of institutional theory on HRM was recognized by Wright and McMahan (1992). Wright and McMahan discussed the implications of theoretical approach to SHRM research and practice. They presented examples of how institutionalization processes may influence SHRM practices. Boselie et al. (2003) used new institutionalism to explain relationship between human resources systems and performance. Paauwe and Boselie (2003) suggested some proposals to represent that the mechanisms of coercive, normative and mimetic institutionalism have an influence on strategic human resource management (see Figure 1). Strategic human resource management not only connects business strategy with human resources management practices but also directs the skills and activities of the company (Wei et al., 2008). Making a decision on human resources management is affected by not only turning to imitating as a result of regulatory pressures and a lack of desire to take risks, but also norms and values which appear as a result of professionalism of working groups in an organization. These institutional mechanisms lead to human resource management homogeneity among organizations. Improving the model that Paauwe and Boselie (2003) propose, we established a model to examine the mediating role of SHRM between mechanisms and stages that are components of institutionalization process.

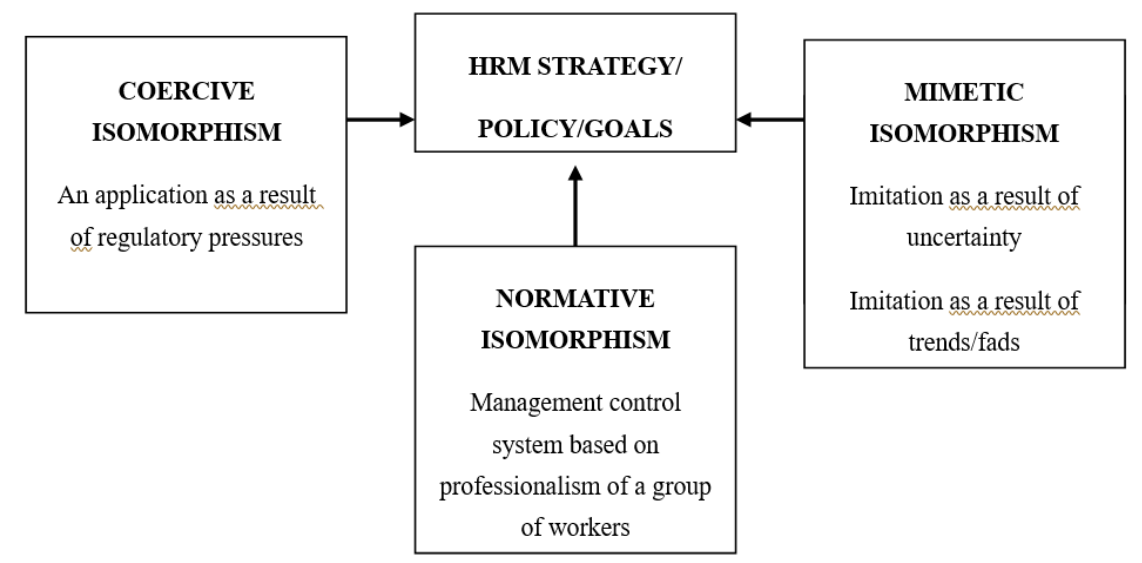

Figure 1. Strategic human resource management and institutionalization (Paauwe \& Boselie, 2003; Boselie et al., 2003) 
In this paper, in which the influence of strategic human resource management on institutionalization process is analyzed, strategic human resource management are defined, its approaches and practices are stated, and then more information about the concept of institutionalization, the mechanisms and stages of institutionalization process are given. Hypotheses are deduced from conceptual information and research model are tested with an experimental analysis, and the results of the research are stated.

\section{Strategic Human Resource Management}

Wright and McMahan (1992) define strategic human resource management as the pattern of planned human resource deployments and activities intended to enable an organization to achieve its goals. Strategic human resource management is the structure of all planned human resources activities required to achieve the targets of the company (Alleyne et al., 2008; Ngo et al., 2008). Strategic HRM is an approach that defines how the organization's goals are achieved through people by means of HR strategies and integrated HR policies and practices (Armstrong, 2008).

Strategic human resource management means all kinds of human resources activities which affect the necessary behaviors for individuals to formulate and apply strategic needs of the company. Furthermore, strategic human resource management is the integration of human resources practices with business strategy both politically and hierarchically in order to facilitate the achievement of organizational aims (Wei et al., 2008). Human resources management practices formulates procedures which institutionalize the building of the knowledge, skills and talents of the workers in the organization in order to improve valuable, unique and non-duplicable organizational skills which support competitive advantage (Werbel \& DeMarie, 2005).

Delery and Doty (1996) have detected seven practices which have been thought as strategic human resources practices for a long time. These are internal career opportunities, formal training systems, appraisal measures, profit sharing, employment security, suggestion mechanisms and job descriptions.

Internal career opportunities express the usage of labor markets. In other words, organizations generally prefer employing people by using internal or external resources (Delery \& Doty, 1996). Managers promote their employees primarily from within the organization and show trust on them and expect greater performance (Khalid et al., 2011). The second practice refers to whether organizations provide comprehensive formal training or depend on improving skills through selection or socialization (Akhtar et al., 2008). Third, appraisals may depend on the results or behaviors. While behavior-based appraisals focus on the behaviors of individuals required performing the job effectively, results-oriented appraisals focus only on the results of these behaviors. Fourth, profit sharing, which attributes pay to organizational performance, is regarded as a complementary part of a strategic human resources system (Delery \& Doty, 1996). Fifth, employment security reflects the level which employees feel safe about carrying on with their jobs (Akhtar et al., 2008). Organizations cannot expect hard 
work, devotion and commitment from their employees in the absence of employment security (Khalid et al. 2011). Sixth, employee participation, both suggestion systems and participation to making a decision are considered as key factors. Finally, the level of defining jobs in a narrow and limited way is very important. Job requirements are more likely to be shaped by well-defined job description than individual action (Delery \& Doty, 1996).

\section{Institutionalization Process}

Institutionalization theory claims that organizations have to be legitimate rather than efficiency and financial success in order to survive for a long time. Different stakeholder types such as government, labor unions and the representative of the professional organizations decide on whether they regard organizations as legitimate or not, and incompatibility with institutionalized environments increases legal cases and the risk of strike. Organizations are embedded in institutional environments and as a result, most of the organizational practices which include human resource management practices come into being from the reflections of structures and laws in these environments as well as the responses given to these environments. Organizations need to adapt their practices to the rules and necessities of these institutional environments in order to get support and be legitimate (Boon et al., 2009).

DiMaggio and Powell (1983) state that when rational actors try to change their organizations, they become more similar to each other. The best term which explains homogeneity process is isomorphism. Isomorphism is a process which forces a unit in a population to become similar to other units which are faced with environmental conditions. There are two types of isomorphism: competitive and institutionalized. Competitive isomorphism expresses a rational system which emphasizes marker orientation as well as changing and suitability measures in niche markets. Also, competitive isomorphism is the most suitable for the ones which are open to the free market and competition. Scientists focus on an alternative viewpoint in order to fully understand the organizational change and that is institutional isomorphism. It is said that three institutional mechanisms affect the decision making in organizations and these are (Boselie et al., 2003):

- Coercive mechanisms resulting from political effect

- Mimetic mechanisms made up of standard responses given to uncertainty

- Normative mechanisms related to professionalization

Coercive mechanisms when they are related to human resources management include the influence of social partners (labor unions and boards of managers), labor law and government. Mimetic mechanisms express the imitation of the strategies and practices of rivals as a result of uncertainty and fashion desires in management. Normative mechanisms express the relationship between management politics and the backgrounds of workers in terms of the level of education, work experience and occupational groups. Occupational groups are related to universities and professional educational firms. These are important focuses in order to 
develop organizational norms between professional managers in the field of finance, marketing, accounting, human resources management and their officer experts as well as counselors (Paauwe \& Boselie, 2003).

When the environment creates uncertainty, organizations tend to model themselves after similar organizations in their field which they see as more legitimate or successful. Applied to HRM, mimetic mechanisms refer to imitations of HR strategies and practices of competitors as a result of uncertainty, or following fads related to HRM (Boon, 2008). Quality circles are an example of a practice that is deemed to be effective in Japanese organizations and then seen in U.S. companies, in spite of the fact that these programs are only occasionally successful (Wright \& McMahan, 1992).

Normative mechanisms stem primarily from professionalization. DiMaggio and Powell (1983) interpret professionalization as the collective struggle of members of an occupation to define the conditions and methods of their work, to control "the production of producers", and to establish a cognitive base and legitimation for their occupational autonomy. Accountants, lawyers, judges, doctors and all of the pilots have to get a professional education before they start their jobs. Professional norms and values such as ethnics and standard work processes are a part of structural education and teaching. After formal educations are completed, occupational groups which they belong to reinforce these norms and values, and so these norms and values are more internalized (Paauwe \& Boselie, 2003).

Coercive isomorphism results from both formal and informal pressures exerted on organizations by other organizations upon which they are dependent and by cultural expectations in the society within which organizations function (Boon, 2008). Coercive mechanisms are embedded in regulatory processes whose forcing levels are different and which show themselves at different levels and in different ways. Regulatory pressures can be thought at international, national and industrial levels when they are related to human resources management (Paauwe \& Boselie, 2003).

Since institutional pressure is special for a country or sector, isomorphism mechanisms may cause the changes in human resources systems to decrease. Institutional demands and requests influence the selection of human resources systems in organizations. For instance, the regulations of government related to basic salary levels for workers and collective job contracts can limit the salary change in certain sectors (Boon et al., 2009).

Barley and Tolbert (1997) define institutions as shared rules and typifications that identify categories of social actors and their appropriate activities or relationships. Institutionalization is the process through the practices that expected in various social settings, are developed and learned (Dillard et al., 2004).

The process of institutionalization is that of creating a social reality between actors through habitualization, objectification, and sedimentation (Zukcer, 1977; Tolbert \& Zucker, 1994; Boons \& Strannegard, 2000). Habitualization involves the generation of new structural arrangements for the resolving of a specific problem. Organizations experiencing a problem 
may also consider solutions developed by others. Objectification which accompanies the diffusion of structure, involves the development of social consensus among organizational decision makers regarding the value of a structure. For example, the spread of formalized selection procedures and performance evaluation procedures in businesses during the period following World War II was influenced by the promotional efforts of members of the emerging occupation of personnel management.Sedimentation involves the complete spreading of structures throughout the group of actors and the continuity of structures over a long period of time (Tolbert \& Zucker, 1994).

\section{Research Methodology}

The purpose of this research is to examine the effect of strategic human resource management on institutionalization process in organizations. Therefore, it is examined the relationship between strategic human resource management practices and mechanisms of institutionalization with stages of institutionalization, and the relationships between mechanisms of institutionalization and stages of institutionalization.

Strategic human resource management practices are measured using internal career opportunities, formal training systems, result-based performance appraisal, profit sharing, employment security, employee participation and job descriptions (Delery \& Doty, 1996). Because profit sharing has one item, it has been taken out of the measurement model. Mechanisms of institutionalization are measured using coercive isomorphism, normative isomorphism and mimetic isomorphism (DiMaggio \& Powell, 1983). Stages of institutionalization are measured using habitualization, objectification and sedimentation (Tolbert \& Zucker, 1994). Three hypotheses are developed to achieve the purpose of this study:

Hypothesis 1: Mechanisms of institutionalization have a significant effect on strategic human resource management practices

Hypothesis 2: Strategic human resource management practices have a significant effect on stages of institutionalization

Hypothesis 3: Mechanisms of institutionalization have significant effect mediation of strategic human resource management practices on the stages of institutionalization

\section{Research Sample}

The population of this study is composed of the firms are located in Kocaeli in Turkey and represented various industries and ownership types. Kocaeli is a "City of Industry and Investment.” The province’s industry based economy accounts for 13\% of Turkey’s Industrial Production. In the past few years the province has developed as a hotspot for the automotive industry, with investments by the sector's heavy hitters such as: Ford, Hyundai, Honda and Isuzu. The major league players of the tyre and rubber sector are here too; Goodyear, Pirelli, Lassa and Bridgestone, all operate in Kocaeli. Nowadays, Kocaeli hosts 1900 industrial investments of which 247 have been established with international capital. Turkey's largest 
enterprise, the Tüpraş Petroleum Refinery Plant, is also located in Kocaeli, where the province supplies $27 \%$ of the national chemical industry (petro-chemical included). 28 of Turkey's 100 largest enterprises are located here. Another meaningful indicator for the province is that out of Turkey's 81 provinces, $13 \%$ of national tax revenues are collected from Kocaeli.

In order to test the hypotheses and achieve the objectives of this research, structured questionnaire was used as a collection data method. This questionnaire is composed of 42 questions that represent all the variables of this research. 140 questionnaires were collected through a survey of 125 enterprises. The enterprises were randomly selected. The majority of these enterprises (80\%) are in the manufacturing sector. At least one informant from each firm was invited to participate in the survey through face-to-face interviews and e-mail. The respondents are medium level managers and senior executives who are authorized in human resources practices and processes in the firms. The people who have participated in the surveys have been asked not only about the human resources practices used in their companies but also about institutionalization.

Research survey includes firstly strategic human resource management, which is composed of six variables, each of which has four questions; secondly, institutional mechanisms which contain three variables, each of which has three questions; and thirdly, institutionalization stages which contain three variables each of which has three questions. The questions regarding the mechanisms of institutionalization were produced from the descriptions done by DiMagggio and Powell (1983). The questions regarding the stages of institutionalization were produced from the descriptions done by Tolbert and Zucker (1994). The answers assessed by using Likert hypothesis scale which has five components changing from 1 which means 'I definitely agree with it' to 5 which means 'I definitely disagree with it'.

\section{Data Analysis}

This study aims to reveal the effect of strategic human resource management on institutionalization process. In the theoretical model in Figure 2 which is developed for this aim, it is shown that three mechanisms which lead to institutionalization process has an effect on strategic human resource management practices, and these practices have an effect on three stages which occur in the process of institutionalization.

In order to examine the hypotheses, reliability and correlations analysis of the data gained from these surveys were done by SPSS 16.0 statistics program; and Structural Equation Modeling analyses of the data gained from these surveys were done by using Lisrel 8.7 statistics program.

Structural equation modeling is a general term used to define a lot of statistical models used to assess the validity of meaningful theories with experimental data (Lei \& Wu, 2007). Structural equation modeling can be regarded as the combination of factor analysis and path analysis (Hox \& Bechger, 1998). Every structural equation modeling analysis is generally made up of defining a model, data collection, determining a model, assessment of a model, 
and model regulation stages (Lei \& Wu, 2007). Field of interest in structural equation modeling is theoretical structures expressed by secret variables. The relationships between theoretical structures are expressed by path coefficients between factors (Hox \& Bechger, 1998).

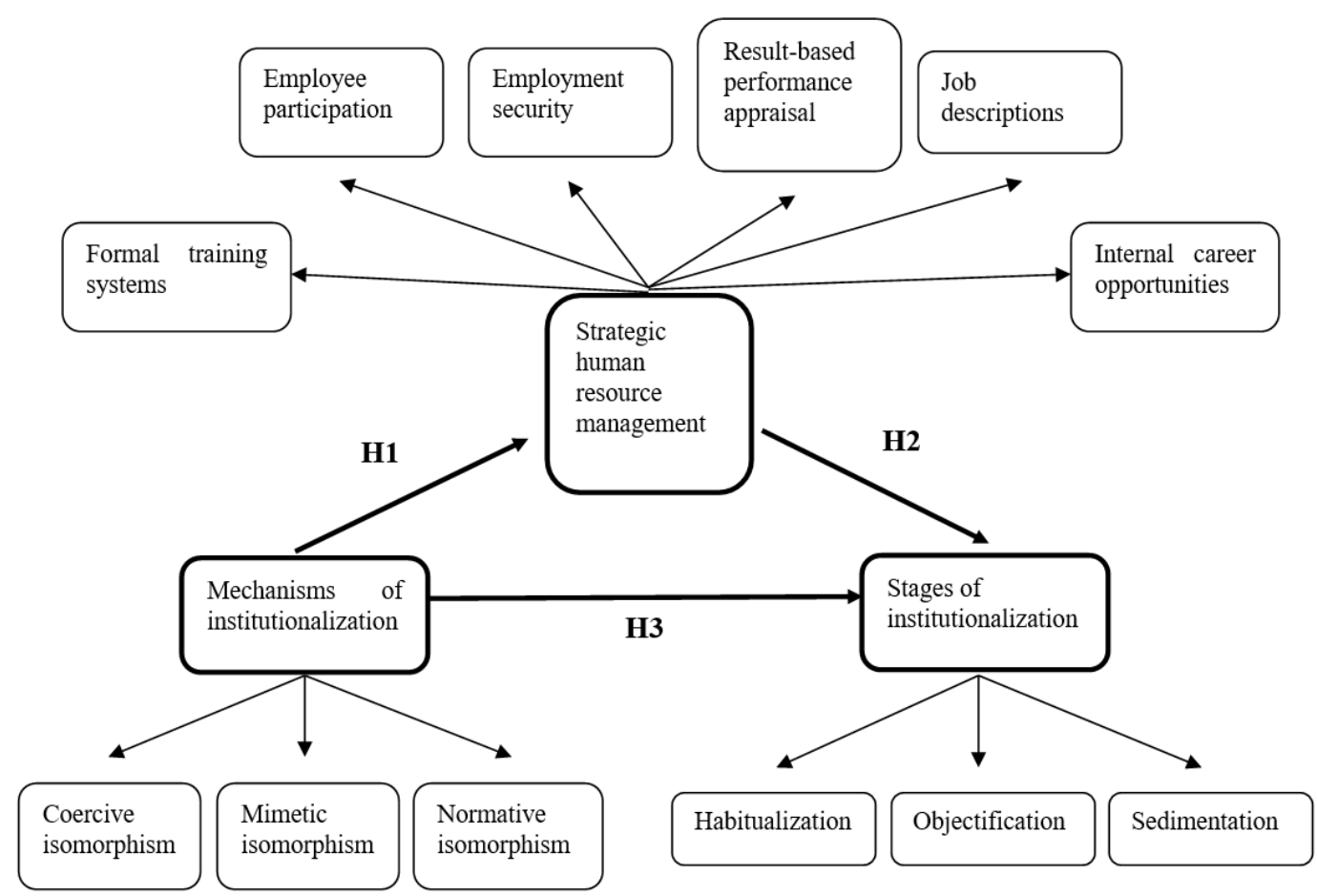

Figure 2. Theoretical Model

In order to examine the hypotheses, reliability and correlations analysis of the data gained from these surveys were done by SPSS 16.0 statistics program; and Structural Equation Modeling analyses of the data gained from these surveys were done by using Lisrel 8.7 statistics program.

Structural equation modeling is a general term used to define a lot of statistical models used to assess the validity of meaningful theories with experimental data (Lei \& Wu, 2007). Structural equation modeling can be regarded as the combination of factor analysis and path analysis (Hox \& Bechger, 1998). Every structural equation modeling analysis is generally made up of defining a model, data collection, determining a model, assessment of a model, and model regulation stages (Lei \& Wu, 2007). Field of interest in structural equation modeling is theoretical structures expressed by secret variables. The relationships between theoretical structures are expressed by path coefficients between factors (Hox \& Bechger, 1998).

In order to test research model, a two-stage approach was used. This two-staged approach depends on a measurement model in the first stage and testing the structural model in the second stage. Validating the measurement model is accomplished through confirmatory factor 
analysis. The measurement model of structural equation modeling is assessed through confirmatory factor analysis. Confirmatory factor analysis allows you to test the relation between variables observed and secret variables on which they are based (Suhr 2006). In the test stage of structural model, the structure of intermediation relations was researched by using alternative model strategy.

\subsection{Reliability}

Cronbach's alpha coefficient which shows the reliability of the scales was calculated. Cronbach's alpha is a model which is used to measure internal consistency. If the alpha coefficient which changes from 0 to 1 is close to 1 , it means that the scale is reliable.

According to the result of first analysis, one item was taken out of formal training systems, job descriptions, internal career opportunities and mimetic isomorphism. After taking out such items mentioned above, a new analysis was conducted. According to this analysis, the reliability of the scale is at an appropriate level. As a result of this analysis, Cronbach's alpha values are presented at Table 1.

Table 1. Reliability Coefficients

\begin{tabular}{lllll}
\hline Measures & Items & Means & $\begin{array}{l}\text { Std. } \\
\text { Deviation }\end{array}$ & $\begin{array}{l}\text { Cronbach's } \\
\text { alpha }\end{array}$ \\
\hline Mechanisms of institutionalization & & & &, 76 \\
\hline Coercive isomorphism & 3 & 4,29 &, 624 &, 70 \\
\hline Mimetic isomorphism & 2 & 3,57 &, 782 &, 83 \\
\hline Normative isomorphism & 3 & 4,16 &, 728 &, 72 \\
\hline Strategic human resource management & & & &, 78 \\
\hline Formal training systems & 3 & 3,89 &, 742 &, 78 \\
\hline Employee participation & 4 & 3,83 &, 699 &, 70 \\
\hline Employment security & 4 & 3,53 &, 911 &, 78 \\
\hline Result-based performance appraisal & 4 & 3,74 &, 735 &, 70 \\
\hline Job descriptions & 3 & 3,79 &, 602 &, 71 \\
\hline Internal career opportunities & 3 & 3,51 &, 704 &, 78 \\
\hline Stages of institutionalization & & & &, 77 \\
\hline Habitualization & 3 & 3,82 &, 574 &, 665 \\
\hline Objectification & 3 & 3,83 &, 621 & \\
\hline Sedimentation & 3 & 3,60 &
\end{tabular}

\subsection{Validity}

The statistics of goodness of fit are used to assess the suitability of measurement and structural model. If the rate which has been reached after dividing $\chi 2$ with df (degree of freedom) is 2 or lower than 2, the model is a good one; and if this rate is 5 or lower than 5 , it shows that this model has an acceptable goodness of fit. If CFI (Comparative Fit Index) is higher than 0,90, it means that it has an acceptable goodness of fit; and if CFI is higher than 0,95, it means that it has a good goodness of fit. If SRMR (Standardized Root Mean Square 
Error) and RMSEA (Standardized Mean Square Error of Approximation) are lower than 0,05, it means that it has a good fit value, and if these rates are lower than 0,08 , it means that it has an acceptable goodness of fit.

The hypothetical model between institutionalization mechanisms, strategic human resource management and the stages of institutionalization was tested in two staged approach to analysis. In the first stage, measurement model was analyzed as a whole and it was analyzed whether it is appropriate for a model tested. The statistics of goodness of fit in hand are $\chi^{2}$ $($ chi square $)=1493.59 ; \mathrm{df}($ degrees of freedom $)=626 ; \chi 2 / \mathrm{df}=2.39, \mathrm{RMSEA}=0.10$, SRMR $=0.05$, CFI $=0.97$. These values show that scale model is generally acceptable. The results of analysis are shown in Table 2. The measurement model obtaining from the analyses is represented in Figure 3.

Table 2. Consequences of confirmatory factor analysis

\begin{tabular}{lccclcccc}
\hline Measure & & $\begin{array}{c}\text { Sdt. } \\
\text { loading }\end{array}$ & t value & Measure & & $\begin{array}{c}\text { Sdt. } \\
\text { loading }\end{array}$ & $\begin{array}{c}\text { t } \\
\text { value }\end{array}$ \\
\hline Formal training & FTS2 & 0,85 & 12,50 & Coercive & CM1 & 0,86 & 12,69 \\
systems & FTS3 & 0,80 & 11,27 & isomorphism & CM2 & 0,85 & 12,39 \\
& FTS4 & 0,74 & 10,09 & CM3 & 0,86 & 12,64 \\
Employee & EP1 & 0,81 & 11,68 & Mimetic & MI2 & 0,85 & 12,34 \\
participation & EP2 & 0,86 & 12,61 & isomorphism & MI3 & 0,89 & 13,29 \\
& EP3 & 0,74 & 10,11 & & & & \\
& EP4 & 0,84 & 12,19 & & & & \\
Employment & & & & & & & \\
security & ES1 & 0,65 & 8,49 & Normative & NM1 & 0,79 & 11,05 \\
& ES2 & 0,60 & 7,81 & isomorphism & NM2 & 0,80 & 11,30 \\
& ES3 & 0,72 & 9,79 & & NM3 & 0,87 & 12,81 \\
Job descriptions & ES4 & 0,69 & 9,27 & & & & \\
& JD1 & 0,86 & 12,67 & Habitualization & H1 & 0,24 & 2,83 \\
Result-based & JD3 & 0,86 & 12,72 & & H2 & 0,95 & 14,95 \\
performance & JD4 & 0,91 & 13,96 & & H3 & 0,93 & 14,41 \\
appraisal & RPA2 & 0,73 & 9,98 & Objectification & O1 & 0,45 & 5,52 \\
Internal & RPA3 & 0,70 & 9,49 & & O2 & 0,80 & 11,37 \\
opportunities & RPA4 & 0,81 & 11,55 & & O3 & 0,66 & 8,78 \\
& ECO2 & 0,80 & 11,35 & Sedimentation & S1 & 0,90 & 13,56 \\
& ECO3 & 0,73 & 9,92 & & S2 & 0,91 & 13,90 \\
& ECO4 & 0,81 & 11,67 & & S3 & 0,91 & 13,86 \\
\hline
\end{tabular}

\subsection{Path Analysis}

Path analysis is an extended regression analysis which includes and multiple regression models equations which are predicted simultaneously. Path analysis can be regarded as a special structural equation model in the modeling of the structural relations among variables observed. Structural relations are hypotheses carried out on the effects of multiple variables and causal relations (Lei \& Wu, 2007).

Testing for the mediation role of strategic human resource management on institutionalization 
process, three regression equations should be estimated (Baron \& Kenny, 1986). According to this method, an independent variable should have an effect on dependent and mediator variable. When a mediator variable is involved in regression analysis with the independent variable, the regression coefficient of the independent variable on dependent variable decreases whereas the meaningful effect of mediator variable on dependent variable continues. The relationship between institutionalization mechanisms and institutionalization stages through hierarchical regression analysis is analyzed with the aim of determining the mediation role of strategic human resource management in this scope. Therefore, two different structural equation models is edited and tested to see direct and indirect effects at the same time.

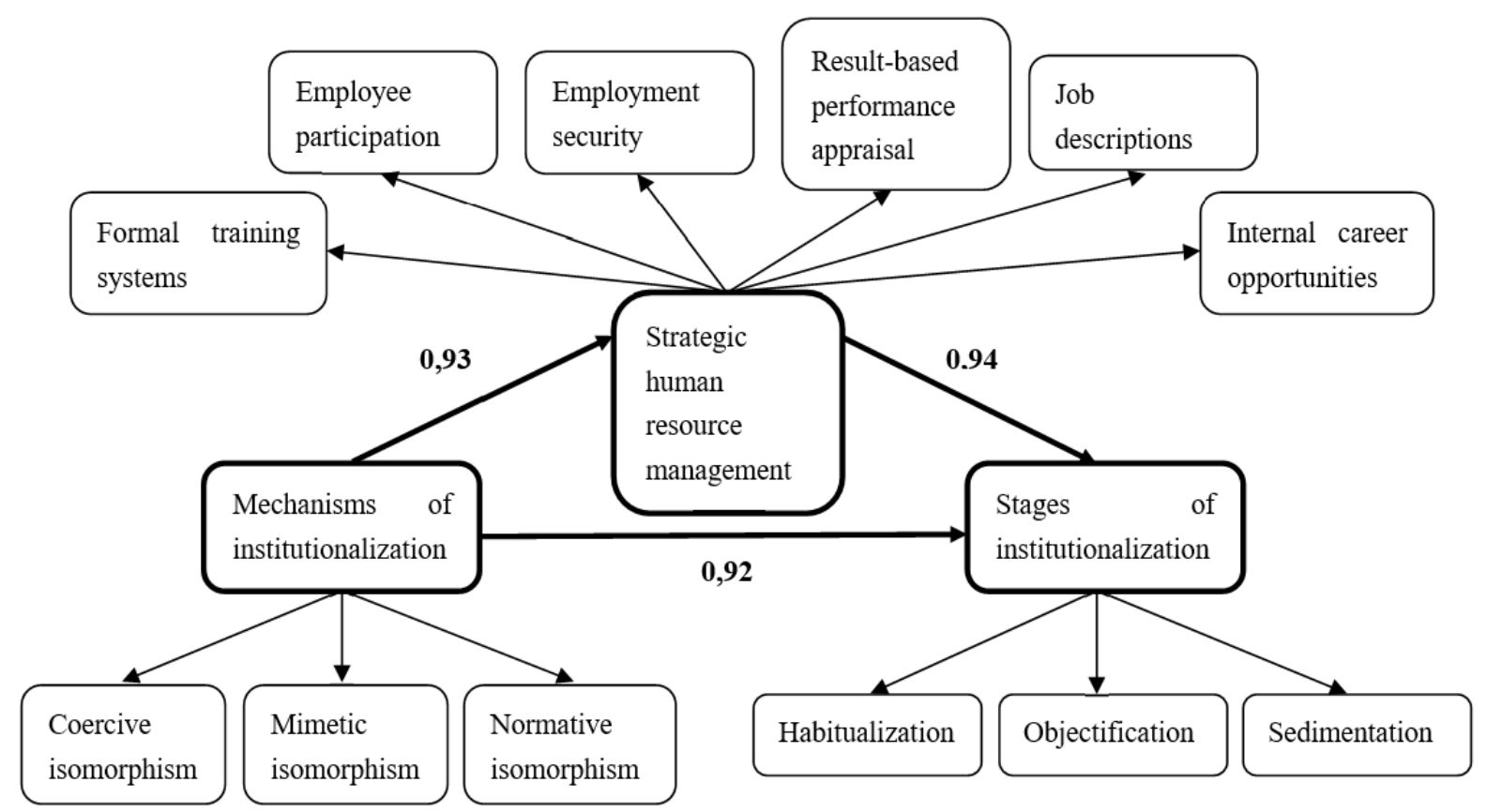

Figure 3. Theoretical Model

In the first model, independent variable was tested with the mechanisms of institutionalization; strategic human resource management was tested as a predictive variable; the stages of institutionalization were tested as predicted variable. As a result of the test of structural model, statistics of goodness of fit are these levels: $\chi^{2}$ (chi square) $=1496.74$; $\mathrm{df}$ $($ degrees of freedom $)=627 ; \chi 2 / \mathrm{df}=2.39, \mathrm{CFI}=0.97, \mathrm{SRMR}=0,052$, and RMSEA $=0.10$ and it has an acceptable goodness of fit; and the hypotheses results related to path analysis, that is represented in Figure 4, are shown in Table 3. According to these results, it is clear that the mechanisms of institutionalization have a positive effect on strategic human resource management, and strategic human resource management has a positive effect on the stages of institutionalization. 


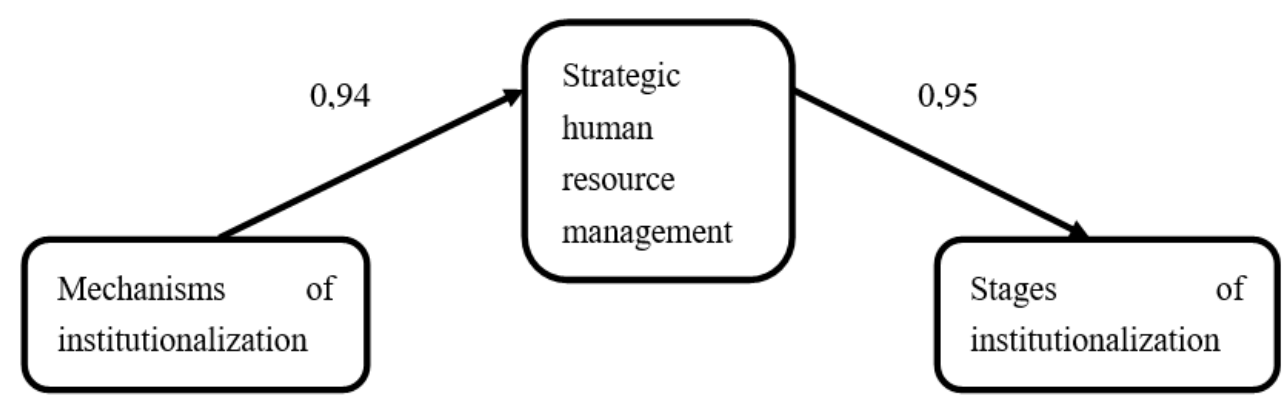

Figure 4. Structural Model 1

Table 3. Model 1 Path Coefficients

\begin{tabular}{llrrrrr}
\hline Structural Path & & $\boldsymbol{\beta}$ & $\mathbf{p}$ & $\mathbf{t}$ & \\
\hline $\begin{array}{l}\text { The Mechanisms of Institutionalization } \\
\text { Human Resource Management }\end{array}$ & $\rightarrow$ & Strategic & 0,94 & 0,00 & 11,60 & supported \\
\hline $\begin{array}{l}\text { Strategic Human Resource Management } \rightarrow \\
\text { Institutionalization }\end{array}$ & The Stages of & 0,95 & 0,00 & 2,85 & supported \\
\hline
\end{tabular}

$\mathrm{t}>1.96$ for $\mathrm{p} \leq 0.05, \mathrm{t}>2.576$ for $\mathrm{p} \leq 0.01$

In the second model of mediation test, the stages of institutionalization was included in the analysis as a dependent variable, and the mechanisms of institutionalization were included in this analysis as an independent variable while strategic human resource management was included as a mediator variable. As a result of a test of the structural model, statistics of goodness of fit are at these levels: $\chi^{2}$ (chi square) $=1493.59$; df (degrees of freedom) $=626$; $\chi 2 / \mathrm{df}=2.39$, CFI $=0.97$, SRMR $=0,052$, and RMSEA $=0.10$ and it has an acceptable goodness of fit; and the hypotheses results related to path analysis, that is represented in Figure 5, are shown in Table 4.

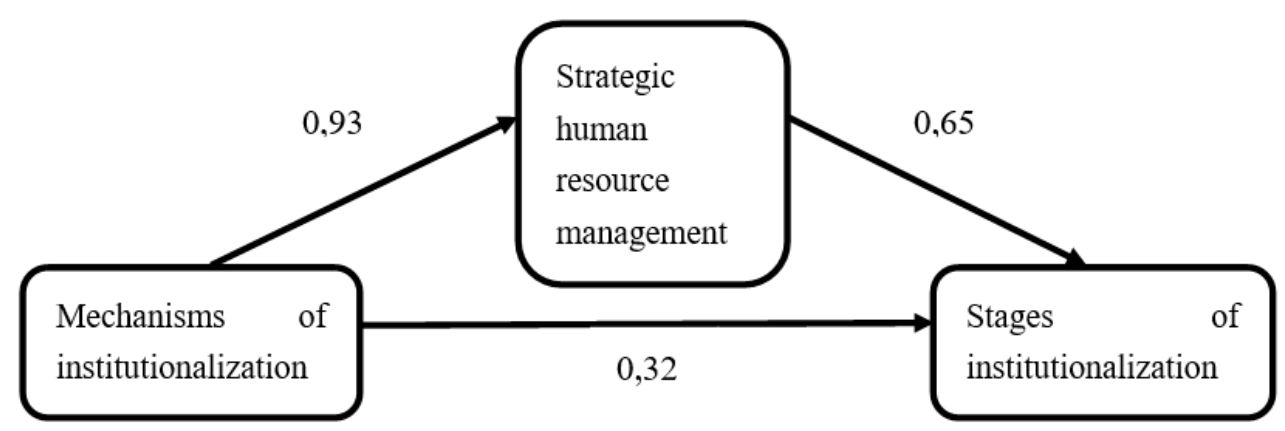

Figure 5. Structural Model 2 
Table 4. Model 2 Path Coefficients

\begin{tabular}{lllllll}
\hline Structural Path & & $\boldsymbol{\beta}$ & $\mathbf{p}$ & $\mathbf{t}$ & \\
\hline $\begin{array}{l}\text { The Mechanisms of Institutionalization } \\
\text { Human Resource Management }\end{array}$ & Strategic & 0,93 & 0,00 & 11,47 & supported \\
\hline $\begin{array}{l}\text { Strategic Human Resource Management } \rightarrow \text { The Stages } \\
\text { of Institutionalization }\end{array}$ & & 0,65 & 0,00 & 2,57 & supported \\
\hline $\begin{array}{l}\text { The Mechanisms of Institutionalization } \rightarrow \\
\text { of Institutionalization }\end{array}$ & The Stages & 0,32 & 0,00 & 2,03 & unsupported \\
\hline
\end{tabular}

$\mathrm{t}>1.96$ for $\mathrm{p} \leq 0.05, \mathrm{t}>2.576$ for $\mathrm{p} \leq 0.01$

According to the findings, when strategic human resource management practices are included in the model, the influence of the mechanisms of institutionalization on the stages of institutionalization become meaningless. According to this, strategic human resource management has the role of mediator variable on the effect of the institutionalization mechanisms on the stages of institutionalization.

\section{Conclusion}

Depending on the study by Paauwe and Boselie (2003), a model which explains the relation between coercive, mimetic and normative isomorphism in the companies, strategic human resource management practices which lead to institutionalization; and habitualization, objectification, and sedimentation which constitute institutionalization process was presented; and by doing so, it was aimed to contribute to the literature.

Paauwe and Boselie (2003) suggested some proposals so as to analyze the effect of coercive, mimetic, and normative institutionalization mechanisms on the shaping of human resources politics and practices in the organizations:

1. The application of the projects suggested by external counselors increases the homogeneity of human resources management in the organizations.

2. Formalized professional management of professional groups and subsequent memberships increases the homogeneity of human resources management in organizations which professionals work for.

3. International and national legislation and instructions increase the homogeneity of human resources management of the company.

These mechanisms are normative mechanisms which express the relation between occupational backgrounds of workers in terms of education level, job experience and mastership; they are coercive mechanisms which include unions of employers, labor unions of workers, work councils, labor law and the effects of the government (Boselie et al., 2003); they are mimetic mechanisms resulting from lack of certainty and lack of desire to take risks (Paauwe \& Boselie, 2003). As a result, all research shows that analyses done through structural equation modeling affect the institutionalization process of strategic human 
resource management.

Normative isomorphism stems from professionalization (DiMaggio \& Powell, 1983). One of important sources of professionalization is formal training. Formal training helps the employees to have the secret information in the organization more easily (Lee \& Lee, 2010). Professional norms and values (for example, in terms of ethics and standard work processes) are a part of this formal training. After completing formal trainings, the professional associations, of which they are members, reinforce these norms and values, and so such norms and values are gradually internalized (Paauwe \& Boselie, 2003).

Internal career opportunities, firstly express employing people within the organization. Selecting employees within the organization causes an organization to be similar (Daley et al., 2002). Selecting employees within the organization helps new structures not only to be widespread in the organization, but also to continue for a long period of time. Thus, internal career opportunities contribute advancement of sedimentation process which defined as the virtually complete spread of structures across the group of actors theorized by the perpetuation of structures over a lengthy period of time (O’Connor, 2011).

Employment security means that workers are not to be fired collectively immediately when the organization has economic problems and face weak performance period (Lee/Lee 2010). Although the most senior employees are not free from layoffs, there are particular groups of employees in organizations who have a greater sense of security in their jobs than other employees, either because of a formal or an informal policy of employment security (Delery \& Doty, 1996).

Employee participation can be defined as the level at which workers assess their contribution and words by encouraging the workers from different hierarchically levels of the organization to participate in decision making process (Lee \& Lee, 2010). Three institutional mechanisms are said to influence decision-making in organizations (Boselie et al., 2001).

Performance appraisals is used as an aid in making judgment decisions pertaining to promotion, demotion, retention, transfer, and pay (Daley et al., 2002). Formal and informal systems of performance appraisal, as a type of isomorphism, cannot be systematically analyzed without getting a deeper perception of the external environment.

Clearly defined jobs indicate that jobs are clearly and precisely defined by well-documented records and written procedures. Thus, employees know how to act or to coordinate their actions to accomplish organizational goals (Lee \& Lee, 2010). The job is limited in scope, and incumbents do not perform duties that are not considered part of the job. The job duties are more likely shaped by a well-defined job description than by individual action (Delery \& Doty, 1996). Well-defined job descriptions accelerate adoption of innovations in response to a specific organizational problem during the habitualization process of institutionalization and diffusion of innovations across the organization. 


\section{Limitations and Recommendations}

This work was tried to contribute to the literature by empirically examining the relationship between strategic human resource management and institutionalization. In addition to the findings of this study also contains some limitations. First, the quantity and quality of sample used in this study are a limitation. Just to be in a specific area of business that is involved in the research, hinders the generalizability of the results of the study. Cross-validation for the firms in other regions this work can be done. In addition, the reliability and validity of the study can be increased by increasing the number of samples. Second, the study is limited to a small set that comprises HR practices used by organizations. Despite their HR practices used in this study generally being strategic, other HR practices may consist of best practices can have a significant unexpected relationship with the company strategy or HR practices can be critical for determining the ideal alternative.

Our model can ensure to improve the different perspectives on the implementation of institutionalization in the future works. Also, the data that obtained from greater surveys allows getting the quality findings.

\section{References}

Abrahamson, E. (1991). Managerial Fads and Fashions: The Diffusion and Rejection of Innovations. Academy of Management Review, 16, 586-612. https://doi.org/10.5465/AMR.1991.4279484

Akhtar, S., Ding, D. Z., \& Ge, G.L. (2008). Strategic HRM Practices and Their Impact on Company Performance in Chinese Enterprises. Human Resource Management, 47(1), 15-32. https://doi.org/10.1002/hrm.20195

Alleyne, P. A., Greenidge, D., Corbin, A., Alleyne, P. G., \& Devonish, D. (2008). The Practice of HRM and SHRM in the Barbados Hotel Sector. Journal of Human Resources in Hospitality \& Tourism, 7(2), 219-240. http://doi.org/10.1080/15332840802157004

Armstrong, M. (2008). Strategic Human Resource Management: A Guide to Action. London and Philadelphia. (4th Ed.). Kogan Page.

Barley, S. R., \& Tolbert, P. S. (1997). Institutionalization and structuration: studying the links between action and institution. Organization Studies, 18, 93-117.

Baron, R. M., \& Kenny, D. A. (1986). The Moderator Mediator Variable Distinction in Social Psychological Research: Conceptual, Strategic, and Statistical Considerations. Journal of Personality and Social Psychology, 51(6), 1173-1182.

Becker, B. E., \& Huselid, M. A. (2006). Strategic Human Resource Management: Where Do We Go from Here? Journal of Management, 32(6), 898-925.

Boon, C. (2008). HRM and Fit: Survival of the Fittest!? ERIM PhD Series Research in Management, 129. 
Boon, C., Paauwe, J., Boselie, P., \& Hartog, D. D. (2009). Institutional Pressures and HRM:

Developing Institutional Fit. Personnel Review, 38(5), 492-508. https://doi.org/10.1108/00483480910978018

Boons, F., \& Strannegard, L. (2000). Organizations coping with their environment. International Studies of Management \& Organization, 30(3), 7-17.

Boselie, P., Paauwe, J., \& Jansen, P. (2001). Human Resource Management and Performance: Lessons from the Netherlands. ERIM Report Series Research in Management.

Boselie, P., Paauwe J., \& Richardson, R. (2003). Human Resource Management, Institutionalization and Organizational Performance: A Comparison of Hospitals, Hotels and Local Government. The International Journal of Human Resource Management, 14(8), 1407-1429. http://doi.org/10.1080/0958519032000145828

Delery, J. E., \& Doty, D. H. (1996). Modes of Theorizing in Strategic Human Resource Management: Tests of Universalistic, Contingency, and Configurational Performance Predictions. Academy of Management Journal, 39(4), 802-835. http://doi.org/10.2307/256713

Daley, D., Vasu, M. L., \& Weinstein, M. B. (2002). Strategic Human Resource Management: Perceptions among North Carolina County Social Service Professionals. Public Personnel Management, 31(3), 359-375.

Dillard, J. F., Rigsby, J. T., \& Goodman, C., (2004). The Making and remaking of organization context: duality and the institutionalization process. Accounting, Auditing \& Accountability Journal, 17(4), 506-542. https://doi.org/10.1108/09513570410554542

DiMaggio, P. J., \& Powell, W. W. (1983). The iron cage revisited: institutional isomorphism and collective rationality in organizational fields. American Sociological Review, 48, 146-60.

Hox, J. J., \& Bechger, T. M. (1998). An Introduction to Structural Equation Modeling. Family Science Review, 11, 354-373.

Karami, A., Analoui F., \& Cusworth, J. (2004). Strategic Human Resource Management and Resource-Based Approach: The Evidence From The British Manufacturing. Industry Management Research News, 27(6), 50-68. https://doi.org/10.1108/01409170410784202

Khalid, J., Latif, A., \& Gillani, S. U. A. (2011). Impact of SHRM Practices on Organizational Performance: An Application of Universalistic Approach. European Journal of Business and Management, 3(3), 316-326.

Lee, C. S., \& Lee, C. H. (2010), Effects of HRM Practices on IT Usage. Journal of Computer Information Systems, 50(2), 83-94.

Lei, P., \& Wu, Q. (2007). Introduction to Structural Equation Modeling: Issues and Practical Considerations. Instructional Topics in Educational Measurement, 26(3), 33-43.

Ngo, H., Lau, C., \& Foley, S. (2008). Strategic Human Resource Management, Firm 
Performance, and Employee Relations Climate in China. Human Resource Management, 47(1), 73-90. http://doi.org/10.1002/hrm.20198

O’Connor, L. (2011). The Institutionalization of Sustainability: Observations from the Australian Local Government Sector. CSEAR 2011 Australasian conference.

Paauwe, J., \& Boselie, P. (2003). Challenging 'Strategic HRM' and the Relevance of the Institutional Setting. Human Resource Management Journal, 13(3), 56-70. http://doi.org/10.1111/j.1748-8583.2003.tb00098.x

Suhr, D. D. (2006). Exploratory or Confirmatory Factor Analysis? SUGI 31 Proceedings, 200-31.

Tolbert, P. S., \& Zucker, L. G. (1994). Institutional Analyses of Organizations: Legitimate but not Institutionalized. Institute for Social Science Research - Biotechnology Studies, 6, 5.

Wan, D., Kok, V., \& Ong, C. H. (2002). Strategic Human Resource Management and Organizational Performance in Singapore. Compensation and Benefits Review, 34(4), 33-42.

Wei, L., \& Lau, C. (2005). Market Orientation, HRM Importance and Competency: Determinants of Strategic HRM in Chinese Firms. The International Journal of Human Resource Management, 16(10), 1901-1918. http://doi.org/10.1080/09585190500298586

Wei, L., Liu, J., Zhang, Y., \& Chiu, R. K. (2008). The Role of corporate culture in the process of strategic human resource management: evidence from Chinese enterprises. Human Resource Management, 47(4), 777-794. http://doi.org/10.1002/hrm.20244

Wei, L., Liu, J., \& Herndon, N. C. (2011). SHRM and Product Innovation: Testing the Moderating effects of Organizational Culture and Structure in Chinese Firms. The International Journal of Human Resource Management, 22(1), 19-33. http://doi.org/10.1080/09585192.2011.538965

Werbel, J. D., \& DeMarie, S. M. (2005). Aligning Strategic Human Resource Management and Person-Environment Fit. Human Resource Management Review, 15, 247-262.

Wright, P. M., \& McMahan, G. C. (1992). Theoretical Perspectives for Strategic Human Resource Management. Journal of Management, 18(2), 295-320.

\section{Copyright Disclaimer}

Copyright for this article is retained by the author(s), with first publication rights granted to the journal.

This is an open-access article distributed under the terms and conditions of the Creative Commons Attribution license (http://creativecommons.org/licenses/by/4.0/). 